\title{
Peran Penyuluhan Pada Persiapan Peremajaan Kelapa Sawit Petani Swadaya Sesuai Konsep ISPO di Kabupaten Rokan Hulu
}

\author{
The Role of Extension in Preparation for the Replanting of Independent \\ Smallholders Oil Palm by the ISPO Concept in Rokan Hulu Regency
}

\author{
Siti Nurul Fadhillah, Rosnita, Novia Dewi \\ Program Studi Agribisnis, Fakultas Pertanian, \\ Universitas Riau, Pekanbaru \\ *Kontak penulis: fadhillahsitinurul@gmail.com
}

\begin{abstract}
The objectives of this study are: (1) Describe the implementation of outreach in distributing information about the ISPO concept. (2) Analyzing the role of extension services in the preparation of oil palm replanting by independent smallholders according to the ISPO concept in Rokan Hulu Regency. The sampling method used was the multistage sampling method with 90 independent oil palm farmers taken as respondents. Descriptive data analysis and using a Likert scale. The results showed: Extension in Rokan Hulu Regency did not go well. On average, the role of extension is less of a role in providing education, dissemination of information, facilitation, consultation, supervision, and monitoring evaluation to independent patterned oil palm farmers, so that farmers are less independent in implementing ISPO
\end{abstract}

Keywords: role of extension, rejuvenation, ISPO

\begin{abstract}
ABSTRAK
Tujuan dari penelitian ini adalah: (1) Mendeskripsikan pelaksanaan penyuluhan dalam mendistribusikan informasi tentang konsep ISPO. (2) Menganalisis peran penyuluhan pada persiapan peremajaan kelapa sawit petani swadaya sesuai konsep ISPO di Kabupaten Rokan Hulu. Metode penentuan sampel yang digunakan adalah metode multistage sampling dengan 90 petani kelapa sawit swadaya diambil sebagai responden. Analisis data secara deskriptif dan menggunakan skala likert. Hasil penelitian menunjukkan: Penyuluhan di Kabupaten Rokan Hulu tidak berjalan dengan baik. Rata- rata peran penyuluhan kurang berperan memberikan edukasi, diseminasi informasi, fasilitasi, konsultasi, supervisi, dan monitoring evaluasi kepada petani sawit pola swadaya, sehingga petani kurang mandiri dalam penerapan ISPO
\end{abstract}

Kata Kunci: peran penyuluhan, peremajaan, ISPO

\section{Pendahuluan}

Perkebunan kelapa sawit di Provinsi Riau merupakan salah satu komoditas yang penting dan strategis karena peranannya cukup besar dalam mendorong perekonomian rakyat, terutama bagi petani perkebunan. Dengan luas mencapai 2.537.375 ha pada tahun 2019, maka daerah Provinsi Riau mempunyai kebun kelapa sawit terluas di Indonesia. Adapun wilayah Rokan Hulu merupakan salah satu kabupaten yang sangat berpotensi sebagai pengembangan komoditas kelapa sawit yang menempati urutan pertama untuk luas areal perkebunan dibandingkan kabupaten lainnya yang ada di Provinsi Riau, yaitu mencapai 480.665 ha (Statistik Perkebunan Provinsi Riau, 2020).

Program peremajaan atau replanting kelapa sawit akan dijalakan di Kabupaten Rokan Hulu. Peremajaan perkebunan sawit rakyat ini merupakan program pemerintah melalui bantuan dana Badan Pengelola Dana Perkebunan Kelapa Sawit ( BPDPKS ) 
yang kondisinya sudah tidak produktif, yaitu usia 25 tahun dan produktivitas di bawah 10 ton tandan buah segar (TBS) per hektar per tahun, rendahnya produktivitas tersebut disebabkan persoalan kualitas benih di masa dahulu. Akibatnya, masyarakat tidak dapat menikmati hasil yang baik, oleh karena itu peremajaan sudah sebaiknya dijalankan untuk meningkatkan kesejahteraan petani. Target replanting yang akan dijalankan di Kabupaten Rokan Hulu sekitar 5.000 hektar.

Menurut Hutasoit et al. (2015), persepsi petani terhadap kegiatan peremajaan sangat baik. Hal ini berimplikasi pada tingginya tingkat kesiapan petani untuk melakukan peremajaan kelapa sawit saat umur tanaman kelapa sawit sudah tidak produktif lagi. Petani telah mengetahui pentingnya peremajaan untuk menjaga keberlanjutan usaha perkebunan kelapa sawit. Petani juga telah memperoleh berbagai pelatihan mengenai pentingnya kegiatan peremajaan bagi keberlanjutan usaha perkebunan kelapa sawit yang lestari. Peremajaan dilakukan berdasarkan teori produksi kelapa sawit.

Hasil peremajaan yang baik tidak hanya berdasarkan perencanaan dan teknik yang baik, namun juga berdasarkan tanggung jawab perusahaan terhadap lingkungan di sekitarnya. Pada tahun 2011 pemerintah Indonesia memberlakukan kebijakan yang mengatur pengelolaan kelapa sawit yaitu pedoman perkebunan kelapa sawit Indonesia atau Indonesia Sustainable Palm Oil (ISPO) dan pada tahun 2015 terdapat perbaikan standar yang dirancang baik untuk petani dengan skema kontrak dengan pabrik pengolahan tertentu maupun untuk sertifikasi kelompok petani swadaya. Penerapan ISPO bertujuan untuk memelihara lingkungan, meningkatkan kegiatan ekonomi, sosial dan penegakan peraturan perundangan Indonesia di bidang perkelapa-sawitan (ISPO 2015). Sertifikasi sebagai alat untuk menciptakan petani yang lebih berkelanjutan, tidak sepenuhnya dipahami oleh petani kecil. Purnaningsih (2018) mengatakan di sisi lain hampir semua petani di wilayah penelitian masih awam terhadap penerapan ISPO, bahkan petani tidak mengetahui tentang peraturan ISPO.

Peranan penyuluh dan pihak yang mau meningkatkan kemampuan petani swadaya sangat dibutuhkan untuk mengatasi kondisi ini khususnya di lokasi penelitian yang masih kurangnya peranan penyuluhan. Dukungan penyuluhan akan meningkatkan produktivitas perkebunan terutama perkebunan kelapa sawit pola swadaya. Masyarakat akan menjadi lebih peka, cerdas, dan antisipatif terhadap segala resiko. Walaupun lahan perkebunan yang luas dan jumlah penyuluh yang banyak, tidak bisa dipungkiri bahwa masih banyak masalah yang dihadapi oleh petani, yang disebabkan keterbatasan pengetahuan petani serta kurangnya tenaga penyuluh pertanian untuk petani kelapa pola swadaya. Kepemilikan faktor produksi seperti; mesin, pupuk pestisida dan benih bersertifikat juga masih menjadi tantangan bagi petani swadaya. Masih banyak petani yang menggunakan benih kelapa sawit tidak bersertifikat sehingga hasil yang diperoleh tidak terjamin kualitasnya. Berdasarkan uraian tersebut maka tujuan penelitian ini adalah mendeskripsikan pelaksanaan penyuluhan dalam mendistribusikan informasi tentang konsep ISPO dan menganalisis peran penyuluhan pada persiapan peremajaan kelapa sawit petani swadaya sesuai konsep ISPO di Kabupaten Rokan Hulu. 


\section{Metode Penelitian}

Penelitian ini dilakukan di Kabupaten Rokan Hulu dipilih 3 kecamatan yaitu Kecamatan Rambah Samo, Rambah Hilir, dan Kepenuhan Hulu sebagai sample area representatif dimana ketiga kecamatan sampel ini merupakan wilayah yang luas tanaman kelapa sawit yang menghasilkan sekaligus tanaman kelapa sawit yang tua dan rusak ( TTR). Masing-masing sampel area diambil 3 desa representatif sebagai sample location. Penentuan sampel responden dilakukan dengan metode purposive sampling. Metode yang dilakukan dengan metode survey dengan melakukan pengamatan langsung ke lapangan dan melakukan wawancara kepada responden petani kelapa sawit swadaya. Penentuan sampel lokasi dilakukan dengan multistage sampling. Sebanyak 90 reponden petani kelapa sawit swadaya di Kabupaten Rokan Hulu diambil sebagai sampel dengan kategori sawit swadaya dewasa (13-20 tahun) dan tua ( >20 tahun) dan sampel relatif homogen dengan areal kelapa sawit petani swadaya tidak menyebar. Masing-masing di setiap kecamatan diambil 3 desa dengan jumlah responden sebanyak 10 orang petani kelapa sawit swadaya per desa.

Data primer yang diperlukan berupa identitas petani sampel, usahatani kelapa sawit, peran penyuluhan, tujuan penyuluhan dalam penerapan setiap prinsip dan kriteria ISPO yang dilakukan petani. Dalam sertifikasi ISPO untuk perkebunan besar tercantum tujuh prinsip, 41 kriteria dan 126 indikator pada aturan untuk membangun industri kelapa sawit kearah lebih positif. Beberapa prinsip dalam ISPO mencakup masalah teknis perkebunan, masalah legalitas perkebu. Prinsip dan kriteria ISPO bagi perkebunan kelapa sawit pekebun swadaya (ISPO, 2015) :

Prinsip 1. Legalitas Pekebun Swadaya

Prinsip 2. Organisasi Pekebun dan Pengelolaan Kebun Swadaya

Prinsip 3. Pengelolaan dan Pemantauan Lingkungan

Prinsip 4. Peningkatan Usaha Secara Berkelanjutan

Data sekunder yang dibutuhkan antara lain jumlah penduduk, pendidikan,luas areal kelapa sawit dan lembaga-lembaga penunjang lainnya. Pelaksanaan penyuluhan dalam mendistribusikan informasi tentang konsep ISPO dianalisis secara deskriptif dan peran penyuluhan dianalisis dengan skala likert. Skor nilai jawaban tertutup dibuat dalam bentuk pernyataan positif (jawaban yang diharapkan) diberi nilai 5 hingga pernyataan negatif (jawaban yang tidak diharapkan) diberi skor 1 .

Dari total nilai pokok skala yang dikelompokkan menjadi lima kategori pernyataan dapat dihitung dengan menggunakan rumus :

$$
\text { Rentang skala }=\frac{\text { Skor Maksimum }- \text { Skor Minimum }}{\text { Jumlah kategori }}-0,01
$$

$$
\frac{5-1}{5}-0,01=0,79
$$

Sumber: Sugiyono, 2015

Perhitungan yang diperoleh dari rentang skala diatas kemudian digunakan sebagai rentang skala penilaian untuk skor nilai jawaban tertutup untuk peran penyuluhan. Skala penilaian dapat dijabarkan pada Tabel 1. 
Tabel 1.

Skala skor dan kategori peran penyuluhan kelapa sawit pola swadaya di Kabupaten Rokan Hulu.

\begin{tabular}{rccl}
\hline \multirow{2}{*}{ No } & \multirow{2}{*}{ Skala } & Skor & Kategori \\
\cline { 4 - 4 } & & & Peran Penyuluh \\
2 & 4 & $4,20-5,00$ & Sangat Berperan \\
3 & 3 & $3,40-4,19$ & Berperan \\
4 & 2 & $2,60-3,39$ & Cukup Berperan \\
5 & 1 & $1,80-2,59$ & Kurang Berperan \\
\hline
\end{tabular}

Sumber: Sugiyono, 2015

\section{Hasil dan Pembahasan}

\section{Karakteristik Petani}

Karakteristik petani responden terdiri dari, umur, tingkat pendidikan,jumlah anggota rumah tangga, luas lahan, pengalaman usahatani dan pengalaman usahatani. Pada penelitian ini karakteristik responden yang ditampilkan adalah karakteristik petani yang memiliki persentasi terbesar. Berikut disajikan karakteristik petani responden dapat di lihat pada Tabel 2.

\section{Tabel 2}

Karakteristik Petani kelapa sawit pola swadaya di Kabupaten Rokan Hulu

\begin{tabular}{clcc}
\hline No & \multicolumn{1}{c}{ Karakteristik Petani Responden } & $\begin{array}{c}\text { Jiwa } \\
\text { (Orang) }\end{array}$ & Persentase (\%) \\
\hline 1 & Umur (15-64) & 85 & 94.4 \\
2 & Pendidikan ( SMA) & 31 & 34.4 \\
3 & Jumlah Anggota Rumah tangga ( $\geq 4$ (Kecil) & 57 & 63.3 \\
4 & Luas Lahan (> 2 Ha) & 57 & 63.3 \\
5 & Pengalaman Usahatani (16-25 Th) & 44 & 48.9 \\
\hline
\end{tabular}

Umur merupakan faktor penting dalam pencapaian keberhasilan suatu usaha. Umur akan mempengaruhi daya berpikir seseorang dalam penentuan keputusan, mengambil resiko dan pola pikir dalam adopsi inovasi. Menurut Badan Pusat Statistik (2017), penduduk produktif yaitu penduduk yang berumur 15 hingga 64 tahun dan yang tidak produktif yaitu penduduk yang berumur 65 tahun keatas. Pada penelitian ini karakteristik responden yang disajikan adalah persentase terbesar yaitu sebesar 94,4 persen berkisar antara 15-64 tahun dengan jumlah 85 orang.

Tingkat pendidikan dapat mempengaruhi cara berfikir dan proses pengambilan keputusan dalam menjalankan suatu usaha. Umumnya seseorang yang berpendidikan tinggi, lebih mudah menerima masukan dan mampu mengembangkan usahanya lebih maju dibandingkan dengan seseorang yang tingkat pendidikannya yang rendah. Tingkat pendidikan diklasifikasikan berdasarkan tidak tamat SD, SD, SMP, SMA sederajat dan Perguruan Tinggi. Pada penelitian ini karakteristik responden yang di 
sajikan adalah yang memiliki persentase terbesar yaitu 34,4 persen pada tingkat pendidikan SMA sebanyak 31 orang.

Jumlah anggota rumah tangga merupakan jumlah seluruh anggota rumah tangga yang segala kebutuhan hidupnya ditangggung oleh kepala rumah tangga sehingga akan berpengaruh pada aktivitas dan cara pengambilan keputusan. Jumlah anggota rumah tangga secara langsung mempengaruhi tingkat pendapatan perkapita rumah tangga. Pada penelitian ini karakteristik responden yang disajikan adalah yang memiliki persentase terbesar yaitu 63,3 persen pada kategori jumlah anggota rumah tangga lingkup kecil $\geq 4$ dengan jumlah responden 57 orang.

Salah satu faktor yang sangat berpengaruh terhadap pendapatan adalah luas lahan pertanian yang dimiliki. Semakin luas lahan pertanian yang dimiliki maka akan berbanding lurus terhadap pendapatan sehingga kemungkinan penambahan pendapatan akan semakin besar. Fadholi dalam Amru (2012) menjelaskan bahwa pada dasarnya ada empat golongan petani berdasarkan luasan tanah yang dimiliki yaitu: (1) Golongan petani luas (>2 ha); (2) Golongan Petani sedang (0,5-2 ha); dan (3) Golongan petani sempit $(<0,5 \mathrm{ha})$. Pada penelitian ini karakteristik responden yang disajikan adalah yang memiliki persentase terbesar yaitu 63,3 persen dengan luas lahan $>2$ ha dengan jumlah responden 57 orang.

Menjalankan usahatani tentunya membutuhkan pengalaman yang baik. Lama usaha yang dijalankan juga akan menambah pengalaman petani terhadap upaya peningkatan produktivitas usahatani petani. Semakin lama petani tersebut menjalankan usahatani yang dikelolanya, maka akan semakin banyak pengalaman yang petani peroleh berdasarkan usahatani yang dikelola. Pada penelitian ini karakteristik responden yang disajikan adalah yang memiliki persentase terbesar yaitu 49,8 persen sebanyak 48 orang degan pengalaman $>16-25$ tahun.

\section{Pelaksanaan Penyuluhan di Kabupaten Rokan Hulu}

Penyuluhan pertanian adalah suatu sistem pendidikan bagi masyarakat khususnya petani untuk membuat mereka tahu, mau dan mampu berswadaya melaksanakan upaya peningkatan produksi, pendapatan/keuntungan dan perbaikan kesejahteraan keluarga/masyarakatnya.Istilah penyuluhan dikenal secara luas dan diterima oleh mereka yang bekerja dalam organisasi pemberian jasa penyuluhan, tetapi tidak demikian halnya bagi masyarakat luas.Karena belum ada definisi yang disepakati, diperlukan untuk memberi pandangan serta dampak yang ditimbulkannya (Mardikanto, 2009).

Penyuluhan di Kabupaten Rokan Hulu tidak berjalan dengan baik. Dulu di perkebunan ada penyuluh yang dinamakan Dinas Cabang Kecamatan penyuluh pada tanaman pangan. Namun kenyataannya setelah pasca reformasi penyuluh di perkebunan sudah tidak ada lagi dan hanya tinggal satu dan statusnya bukan penyuluh, tugasnya bukan penyuluh tapi lebih tepatnya tenaga pendamping yang membantu petani dalam mempersiapkan peremajaan. Sebelum adanya program replanting pemerintah juga membuat program revitalisasi perkebunan pada tahun 2007 yang mengadakan fasiliator daerah sebanyak 2 sampai 3 orang di setiap kabupaten, namun tidak berperan sebagai penyuluhan. Secara umum kondisi dalam pasca otonomi daerah penyuluhan di Kabupaten Rokan Hulu dapat dikatakan ada tapi terasa tidak ada, yang ada hanyalah petugas untuk mendampingi masyarakat dalam penyiapan peremajaan. Penyuluh hanya ada satu atau dua orang dan dilaksanakan dalam 
penentuannya satu kali dalam sebulan, namun kenyataan di lapangan belum maksimal diterapkan. Materi sosialisasi yang disajikan penyuluh hanya usahatani saja dan kurang mensosialisasikan tentang ISPO. Sebagian disisi lain hampir semua petani di wilayah penelitian masih awam terhadap penerapan ISPO, bahkan petani tidak mengetahui tentang peraturan ISPO.

\section{Peran Penyuluhan Dalam Memandirikan Petani Swadaya Pada Peremajaan Sesuai Standar ISPO Di Kabupaten Rokan Hulu}

Penyuluh merupakan media sumber informasi bagi petani untuk mendapat informasi-informasi terbaru baik dari dalam maupun dari luar daerah untuk mengatasi tentang permasalahan yang dihadapi petani baik di bidang pertanian, perikanan, peternakan, perkebunan dan kehutanan. Maju dan berkembangnya petani pada suatu daerah sangat tergantung kepada motivasi dan serta peran aktif seorang penyuluh dalam menjalankan fungsinya sebagai seorang penyuluh.

Peran penyuluhan merupakan suatu rangkaian kegiatan sebagai fasilitasi proses belajar, sumber informasi, pendampingan, pemecahan masalah, pembinaan, pemantauan, dan evaluasi terhadap kegiatan petani untuk mendukung pembangunan pertanian yang berkelanjutan. Dalam kegiatan pertanian diperlukan kehadiran peran penyuluhan sebagai pemicu sekaligus sebagai pemacu pembangunan pertanian di Indonesia (Mardikanto, 2009). Lebih lanjut peran penyuluhan akan diuraikan sesuai dengan indikator yang menggambarkan peran penyuluhan.

Tabel 3.

Peran penyuluhan (pendamping) dalam memandirikan petani swadaya pada peremajaan sesuai standar ISPO di Kabupaten Rokan Hulu

\begin{tabular}{clcl}
\hline No & \multicolumn{1}{c}{ Peran Penyuluhan } & Skor & Kategori \\
\hline 1 & Edukasi & 2.05 & Kurang Berperan \\
2 & Diseminasi & 2.00 & Kurang Berperan \\
3 & Fasilitasi & 2.04 & Kurang Berperan \\
4 & Konsultasi & 2.02 & Kurang Berperan \\
5 & Supervisi/Pembinaan & 1.96 & Kurang Berperan \\
6 & Monitoring dan Ealuasi & 2.02 & Kurang Berperan \\
\hline & Rata-rata keseluruhan & $\mathbf{2 . 0 1 5}$ & Kurang Berperan \\
\hline
\end{tabular}

Tabel 3 tampak secara jelas bahwa peran penyuluhan yang ada di Kabupaten Rokan Hulu masih " Kurang Berperan" dari semua variabel peran penyuluh yang ada dengan skor 2.015. Ini adalah sebuah gambaran penyuluhan yang ada di daerah tersebut. Penyuluhan masih banyak kurang aktif dan masih sedikit petani yang masuk ke dalam kelompok tani. Penyuluh kurang berperan dalam melakukan kegiatan usahatani kelapa sawit swadaya yang sesuai dengan standar ISPO bahkan hanya sebagian petani yang mengetahui istilah ISPO, masih kurangnya penyebaran informasi mengenai replanting, kurangnya memotivasi minat dalam berusahatani, kurang melakukan pembinaan kemampuan teknik petani dalam usahatani kelapa sawit dan pemasaran hasil pertanian, penyuluh jarang membina pemanfaatan pengelolaan sumber daya alam (SDA) dan sumber daya manusia (SDM) berkelanjutan, Penyuluh kurang dalam memfasilitasi terhadap keluhan petani. Penyuluh kurang dalam membantu akses petani ke lembaga keuangan. Penyuluh kurang dalam konsultasi 
pemecahan masalah yang dihadapi petani. Penyuluh masih perlu meningkatkan pembinaan kemampuan teknik usahatani dari hulu-hilir. Perlunya peningkatan dalam pemasaran hasil usahatani kelapa sawit. Penyuluh jarang melakukan monitoring dan evaluasi usahatani kelapa. Penyuluh jarang melakukan monitoring dan evaluasi penguasaan inovasi atau teknologi baru. Penyuluh jarang melakukan evaluasi hasil kegiatan usahatani output penyuluhan.

Supervisi/pembinaan merupakan aspek terendah dari 6 aspek peran penyuluhan memiliki skor rata-rata 1,96 dikarenakan penyuluh kurangnya memberi edukasi kepada petani mengenai sertifikasi ISPO bahkan sangat jarang sekali penyuluh menyinggung mengenai ISPO maka petani masih kurang mengetahui pemenuhan sertifikasi ISPO, seperti legalitas kebun pekebun, organisasi pekebun, pengelolaan pekebun dan pemantauan lingkungan, dan peningkatan usaha berkelanjutan. Dari awal penyuluh kurang melakukan edukasi kepada petani mengakibatkan ke 6 aspek peran penyuluhan dirasakan petani swadaya masih dikategorikan kurang berperan, terutama peran penyuluh terkait supervisi/pembinaan sangat kurang dijalankan sehingga skor rata-rata supervisi lebih rendah dibandingkan edukasi, diseminasi, fasilitasi, konsultasi dan monitoring/evaluasi.

Kerjasama antara penyuluh dan petani perlu ditingkatkan agar kegiatan penyuluhan yang dilakukan dapat terlaksana dengan baik dan manfaatnya dapat dirasakan oleh petani. Penyuluh juga dituntut untuk berperan aktif dalam mengajak petani untuk berpartisipasi dalam setiap kegiatan yang diadakan oleh penyuluh serta penyuluh lebih banyak mensosialisasikan tentang persiapan peremajaan yang sesui dengan konsep ISPO dan membantu petani dalam pemenuhan sertifikasi ISPO.

\section{Kesimpulan}

Penyuluhan di Kabupaten Rokan Hulu tidak berjalan dengan baik, penyuluh di perkebun belum ada hanya ada tenaga pendamping yang membantu petani dalam mempersiapkan peremajaan. Penyuluh kurang memberikan sosialisasi tentang penerapan sertifikasi ISPO kepada petani sawit swadaya sehingga standar ISPO seperti legalitas lahan, pengelolaan kebun, pengelolaan pemantauan lingkungan serta meningkatkan usaha secara berkelanjutan kurang berjalan di daerah penelitian. Banyaknya kelompok tani yang kurang aktif dan petani masih banyak yang belum bergabung dalam kelompok tani. Penyuluhan di Kabupaten Rokan Hulu kurang berperan memberikan edukasi, diseminasi informasi, fasilitasi, konsultasi, supervisi, dan monitoring evaluasi kepada petani kelapa sawit swadaya.

\section{Daftar Pustaka}

Andoko A \& Widodo. (2013). Berkebun Kelapa Sawit si Emas Cair. PT Agro Media Pustaka.

Badan Pusat Statistik. (2017). Umur produktif penduduk. https://www.bps.go.id.

Badan Pusat Statistik Kabupaten Rokan Hulu. (2019). Kabupaten Rokan Hulu dalam Angka. Badan Pusat Statistik Rokan Hulu.

Badan Pusat Statistik Provinsi Riau. (2020). Provinsi Riau dalam Angka. Badan Pusat Statistik Riau. 
Djaali. (2008). Skala Likert. Pustaka Utama.

Hidayat, GlasbergePn, dan O. (n.d.). Sustainability Certification and Palm Oil Smallholders' Livelihood: A Comparison between Scheme Smallholders and Independent Smallholders in Indonesia. International Food and Agribusiness Management Association (IFAMA). ). All Rights Reserved. Volume18 Issue 3.

Hutasoit, F., Hutabarat, S., Muwadi, D. (2015). Analisis persepsi petani kelapa sawit swadaya bersertifikasi RSPO dalam menghadapi kegiatan peremajaan perkebunan kelapa sawit di Kecamatan Ukui, Kabupaten Pelalawan. Jurnal Faperta Vol 2 No 1. Universitas Riau. Riau, ID.

ISPO. (2015). Indonesian Sustainable Palm Oil. Retrieved from http://www.ispo-org.or.id.

Kementerian Pertanian. (2015). Peraturan Menteri Pertanian Republik Indonesia Nomor: 11/Permentan/OT.140/3/2015 tentang Sistem Sertifikasi Kelapa Sawit Berkelanjutan Indonesia. Kementerian Pertanian Republik Indonesia, Jakarta.

Lestari, M. (2011). Dinamika Kelompok Dan Kemandirian Anggota Kelompok Tani Dalam Berusahatani Di Kecamatan Poncowarno Kabupaten Kebumen Propinsi Jawa Tengah. Program Pasca Sarjana Universitas Sebelas Maret Surakarta.

Mardikanto, T. (2009). Penyuluhan Pembangunan Pertanian. Sebelas Maret University Press. Surakarta.

Nurkhoiry R., Agustira M.A., Wahyono T., Moechtar D., Kurniawan A., H. I. Y. dan K. A. . (2006). Pedoman Norma Kerja Perkebunan Kelapa Sawit pada Lahan Mineral. Pusat Penelitian Kelapa Sawit, Medan.

Pahan I. (2008). Panduan Lengkap Kelapa Sawit: Manajemen Agribisnis dari Hulu hingga Hilir. Penebar Swadaya, Jakarta.

Purnaningsih, N., \& Sadono, D. (2018). Jurnal Penyuluhan, Maret 2018 Vol. 14 No. 1 Persepsi Petani tentang Peranan Penyuluh dalam Peningkatan Produksi Padi di Kecamatan Tabir Kabupaten Merangin Provinsi Jambi. 14(1).

Rosnita, Yulida, R. A. (2012). Tingkat keberdayaan Lembaga Keuangan Mikro dalam peningkatan produksi kelapa sawit di Provinsi Riau. Junal penyuluhan,Vol.13 No.2

Sugiyono. (2015). Statistika Untuk penelitian. Alfabeta.Bandung. 